\title{
Pt Electrocatalyst Prepared by Hydrothermal Reduction onto the Gas Diffusion Layer for High-Temperature Formic Acid and Ethanol Fuel PEMFC
}

\author{
Rayane da Silva Cardoso ${ }^{1}$, Bruna Sartório de Castro ${ }^{1}$, Sophya de Andrade Dias ${ }^{1}$, Maria Clara H. Clemente ${ }^{1}$, \\ Sílvia C. L. Dias ${ }^{1}{ }^{1}$, José A. Dias ${ }^{1}{ }^{(\mathbb{C}}$, Rudy Crisafulli ${ }^{1}$, José J. Linares ${ }^{2}{ }^{\mathbb{D}}$ and Gesley A. Veloso Martins ${ }^{1, *}$
}

1 Laboratório de Catálise, Instituto de Química, Campus Universitário Darcy Ribeiro, Universidade de Brasília, Brasília 70910-900, DF, Brazil; rayanedsc32@gmail.com (R.d.S.C.); bruna.sartorio18@gmail.com (B.S.d.C.); sophyadias@gmail.com (S.d.A.D.); mrclara01@gmail.com (M.C.H.C.); scdias@unb.br (S.C.L.D.); jdias@unb.br (J.A.D.); rudycrisafulli@gmail.com (R.C.)

2 Laboratório de Desenvolvimento de Processos Químicos, Instituto de Química, Campus Universitário Darcy Ribeiro, Universidade de Brasília, Brasília 70910-900, DF, Brazil; joselinares@unb.br

* Correspondence: gesley@unb.br; Tel.: +55-61-3107-3866

Citation: da Silva Cardoso, R.; de Castro, B.S.; de Andrade Dias, S.; Clemente, M.C.H.; Dias, S.C.L.; Dias, J.A.; Crisafulli, R.; Linares, J.J.; Veloso Martins, G.A. Pt Electrocatalyst Prepared by Hydrothermal Reduction onto the Gas Diffusion Layer for High-Temperature Formic Acid and Ethanol Fuel PEMFC. Catalysts 2021, 11, 1246. https://doi.org/10.3390/ catal11101246

Academic Editor: Edward G. Gillan

Received: 18 September 2021

Accepted: 14 October 2021

Published: 17 October 2021

Publisher's Note: MDPI stays neutral with regard to jurisdictional claims in published maps and institutional affiliations.

Copyright: (c) 2021 by the authors. Licensee MDPI, Basel, Switzerland. This article is an open access article distributed under the terms and conditions of the Creative Commons Attribution (CC BY) license (https:// creativecommons.org/licenses/by/ $4.0 /)$.

\begin{abstract}
An alternative method for the preparation of PEMFC electrodes is presented in this work based on the direct deposition of Pt particles onto the gas diffusion layer (Pt@GDL) by hydrothermal reduction of the $\mathrm{H}_{2} \mathrm{PtCl}_{6}$ precursor from formic acid, ethylene glycol, and ethanol reductive solutions There is a successful anchorage of $\mathrm{Pt}$ particles via the formation of $\mathrm{Pt}$ crystal aggregates. The influence of the reducing agent concentration and temperature was studied to analyze their influence on the size, morphology, and distribution of the Pt particles on the gas GDL. The prepared Pt@GDL was tested for formic acid and ethanol high-temperature $\mathrm{H}_{3} \mathrm{PO}_{4}$-doped PEMFC. The Pt@GDL prepared in the formic acid reductive atmosphere presented the best performance associated with the formation of smaller Pt crystals and a more homogeneous dispersion of the Pt particles. For formic acid and ethanol-fed high-temperature PEMFC using a $\mathrm{H}_{3} \mathrm{PO}_{4}$-doped polybenzimidazole membrane as the solid electrolyte, maximum power densities of 0.025 and $0.007 \mathrm{~W} \mathrm{~cm}^{-2}$ were drawn at $200{ }^{\circ} \mathrm{C}$, respectively.
\end{abstract}

Keywords: electrocatalysts; direct deposition; platinum; high temperature PEMFC; hydrogen; ethanol; formic acid; polybenzimidazole

\section{Introduction}

Over the last few years, there has been a solid worldwide commitment for increasing the participation of renewable energies sources (RES) in the energy panorama [1]. This has stimulated the development of sustainable routes to produce liquid fuels as a part of the portfolio of RES. Bioethanol is already a reality produced from the sugarcane or corn alcoholic fermentation [2]. Formic acid is also emerging as a candidate as it can be synthesized from biomass or from $\mathrm{CO}_{2}$ capture [3]. For instance, bioethanol is extensively used as fuel replacing gasoline in the USA and Brazil [4]. In addition to its renewable origin, ethanol possesses some advantages such as the high volumetric energy density, $6.4 \mathrm{kWh} \mathrm{L}^{-1}$ [5], non-toxicity, and its logistics can be easily coupled to gasoline. In the case of formic acid, it is a low-flammable, biodegradable, and stable liquid under ambient conditions, with an operating temperature range between 8.3 and $101^{\circ} \mathrm{C}$ [6-8], facilitating the storage and transportation issues.

Such features have stimulated the development of the Direct Formic Acid Fuel Cells (DFAFC) and Direct Ethanol Fuel Cells (DEFC) as an alternative to $\mathrm{H}_{2}$-feed Polymer Electrolyte Membrane Fuel Cells, especially for portable applications in the view of some issues associated to the production (and purification), distribution, storage, and safety of $\mathrm{H}_{2}$, regardless of its off- or on-board generation [9]. DFAFC and DEFC have experienced 
notable advances in the last few years by preparing more active electrocatalysts, aiming at reducing the poisoning of the electrocatalysts due to the formation of strongly adsorbed carbonaceous residues, less permeable membranes to the fuel and comburent, and more tolerant fuel cathodes $[10,11]$. Conventionally, DFAFC and DEFC use a perfluosulfonated polymeric membrane (Nafion ${ }^{\circledR}$ or similar polymers), whose operating temperature does not exceed $90^{\circ} \mathrm{C}$. Some of the mentioned limitations are related with this low operating temperature, including the necessity of noble metals ( $\mathrm{Pt}$ or Pt-based bi-, tri- or multimetallic electrocatalysts) and the application of high metal loadings (>1 mg cm$\left.{ }^{-2} \mathrm{of} \mathrm{Pt}\right)$. The increase of the cell operating temperature can help to mitigate them, as already evidenced for DEFC [12-15] and DFAFC [16]. For this, an adequate polymeric membrane must be used, such as the $\mathrm{H}_{3} \mathrm{PO}_{4}$-doped polybenzimidazole (PA-PBI), which achieves conductivities well above $0.01 \mathrm{~S} \mathrm{~cm}^{-1}$ up to $200{ }^{\circ} \mathrm{C}$ [17-20].

In the search for reducing the Pt loading as one of the strategies to make fuel cells less costly, new electrode preparation methods are explored. The two main strategies used for preparation of the catalytic layer (CL) are the catalyst-coated membrane (CCM) and catalyst-coated substrate (CCS). In the CCM, the CL is directly applied onto the membrane, which allows a low contact resistance between the catalyst and the membrane electrolyte. In the CCS method, the CL is deposited onto a carbon substrate, generally a porous gas diffusion layer (GDL) (paper, felt or cloth), allowing a more uniform distribution of the catalyst. Both strategies can be applied for printing (screen, inkjet, flexography or spray coating), sputtering, or electrochemical deposition (the latter only applicable to CCS) [21]. The printing procedure generally uses carbon-supported Pt electrocatalyst and requires the preparation of an ink. In the case of the sputtering method, a Pt target is used to bombard the membrane or carbon substrate to form a thin film of pure Pt. Finally, the electrochemical deposition allows the direct deposition of the Pt particles onto a conductive substrate (usually carbon material) forming thin metal films. The direct deposition by in situ reduction of the Pt precursor onto the GDL can be a practical alternative, reducing the number of steps conventionally required to prepare the electrode, namely, preparation of the supported catalysts, deposition on the GDL, and fabrication of the membrane-electrode assembly (MEA). Successful approaches have been presented by Schröder et al. [22], with the application of $\mathrm{IrO}_{2}$ onto the GDL by vacuum filtration. Salomé et al. [23] prepared by electrodeposition Ag onto a gas diffusion layer (porous carbon paper), pointing out the importance of the plating composition solution and the conditions applied during the electrochemical deposition. Well-dispersed Ag particles in the micrometric range were observed in the micrographies. Pacquets et al. [24] also electrodeposited $\mathrm{Cu}$ onto a gas diffusion layer and studied the influence of the pretreatment (water, $\mathrm{NaOH}$, $\mathrm{HNO}_{3}$, and a commercial surfactant) of the carbonaceous material onto the deposition characteristics. Furthermore, the electrodeposition parameters were of increasing size for larger applied charges and potential. The material was applied for the electrochemical reduction of $\mathrm{CO}_{2}$. A review of these methods can be read in [25]. A recent study of Kim et al. [26] demonstrated the possibility of direct deposition of Pt particles onto the GDL. They observed the formation of interconnected grains whose morphology depended on the ultrasound irradiation parameters and the composition of the precursor/reducing agent composition. The prepared electrodes were tested for $\mathrm{H}_{2}$-PEMFC with satisfactory results.

In this work, we propose an alternative direct deposition of Pt particles onto the carbon support for preparing the fuel cell electrodes by a hydrothermal reduction method. A solution containing the Pt salt precursor is deposited onto the GDL (carbon cloth with a wet-proofed microporous layer (MPL)) to allow the formation of the Pt particles (hereinafter referred to as Pt@GDL). To the best of author's knowledge, there are no studies referring to this deposition method, which might be considered simpler and more rapid for the preparation of fuel cell electrodes. Different reducing agents (formic acid, ethanol, and ethylene glycol) are proposed to observe the effect of the reducing atmosphere (indeed, these chemicals are extensively used for preparing Pt electrocatalyst by chemical reduction in solution [27-29]). The prepared electrodes are physically characterized by thermal 
analysis (TA), X-ray diffractometry (XRD), Energy-Dispersive X-Ray Spectroscopy (EDS) and Scanning Electron Microscopy (SEM). Finally, the Pt@GDL electrodes are tested in a vapor-fed DFAFC and DEFC using a PA-PBI membrane electrolyte under different operating temperatures.

\section{Results and Discussion}

\subsection{Physical Characterization of the Prepared Electrodes}

\subsubsection{Estimation of the Platinum Loading}

In order to verify the actual Pt loading, Table 1 presents the corresponding weight of the different Pt@GDL electrodes after the hydrothermal treatment (also, electrode identification is included). As it can be observed, the final weights are in very well agreement with the nominal Pt loading, validating the method for the success deposition of Pt. Thus, the final average metal loading of the electrodes can be indeed considered $0.5 \mathrm{mg} \mathrm{cm}^{-2}$.

Table 1. Final weight of the thermally treated Pt@GDL to estimate the Pt loading (expected value of $2 \mathrm{mg}$ ).

\begin{tabular}{|c|c|c|c|c|}
\hline $\begin{array}{c}\text { Reducing } \\
\text { Agent }\end{array}$ & $\begin{array}{l}\text { Reducing Agent/Pt } \\
\text { Molar Ratio in the } \\
\text { Hydrothermal } \\
\text { Treatment }\end{array}$ & $\begin{array}{c}\text { Temperature } \\
\left({ }^{\circ} \mathrm{C}\right)\end{array}$ & Identification & $\begin{array}{c}\text { Final Weight } \\
\text { (mg) }\end{array}$ \\
\hline \multirow{3}{*}{$\begin{array}{l}\text { Formic } \\
\text { acid }\end{array}$} & 100 & $\begin{array}{l}120 \\
140 \\
160\end{array}$ & $\begin{array}{l}\text { FA120100 } \\
\text { FA140100 } \\
\text { FA160100 }\end{array}$ & $\begin{array}{l}1.92 \pm 0.06 \\
1.89 \pm 0.12 \\
1.91 \pm 0.05\end{array}$ \\
\hline & 200 & $\begin{array}{l}120 \\
140 \\
160\end{array}$ & $\begin{array}{l}\text { FA120200 } \\
\text { FA140200 } \\
\text { FA160200 }\end{array}$ & $\begin{array}{l}1.92 \pm 0.02 \\
1.89 \pm 0.15 \\
1.91 \pm 0.03\end{array}$ \\
\hline & 300 & $\begin{array}{l}120 \\
140 \\
160\end{array}$ & $\begin{array}{l}\text { FA120300 } \\
\text { FA140300 } \\
\text { FA160300 }\end{array}$ & $\begin{array}{l}1.92 \pm 0.04 \\
1.89 \pm 0.02 \\
1.91 \pm 0.02\end{array}$ \\
\hline \multirow{3}{*}{$\begin{array}{l}\text { Ethylene } \\
\text { glycol }\end{array}$} & 100 & $\begin{array}{l}160 \\
180 \\
200\end{array}$ & $\begin{array}{l}\text { EG120100 } \\
\text { EG140100 } \\
\text { EG160100 }\end{array}$ & $\begin{array}{l}2.02 \pm 0.10 \\
1.99 \pm 0.15 \\
1.93 \pm 0.02\end{array}$ \\
\hline & 200 & $\begin{array}{l}160 \\
180 \\
200\end{array}$ & $\begin{array}{l}\text { EG120200 } \\
\text { EG140200 } \\
\text { EG160200 }\end{array}$ & $\begin{array}{l}1.96 \pm 0.03 \\
1.85 \pm 0.18 \\
1.96 \pm 0.08\end{array}$ \\
\hline & 300 & $\begin{array}{l}160 \\
180 \\
200\end{array}$ & $\begin{array}{l}\text { EG120300 } \\
\text { EG140300 } \\
\text { EG160300 }\end{array}$ & $\begin{array}{l}2.06 \pm 0.03 \\
2.01 \pm 0.06 \\
1.96 \pm 0.07\end{array}$ \\
\hline \multirow{3}{*}{ Ethanol } & 100 & $\begin{array}{l}120 \\
140 \\
160\end{array}$ & $\begin{array}{l}\text { ET120100 } \\
\text { ET140100 } \\
\text { ET160100 }\end{array}$ & $\begin{array}{l}2.08 \pm 0.12 \\
1.86 \pm 0.03 \\
1.94 \pm 0.04\end{array}$ \\
\hline & 200 & $\begin{array}{l}120 \\
140 \\
160\end{array}$ & $\begin{array}{l}\text { ET120200 } \\
\text { ET140200 } \\
\text { ET160200 }\end{array}$ & $\begin{array}{l}1.95 \pm 0.06 \\
1.98 \pm 0.11 \\
2.03 \pm 0.04\end{array}$ \\
\hline & 300 & $\begin{array}{l}120 \\
140 \\
160\end{array}$ & $\begin{array}{l}\text { ET120300 } \\
\text { ET140300 } \\
\text { ET160300 }\end{array}$ & $\begin{array}{l}1.89 \pm 0.13 \\
1.99 \pm 0.08 \\
1.92 \pm 0.09\end{array}$ \\
\hline
\end{tabular}

2.1.2. X-ray Diffractograms of the Samples

Figure 1 presents the diffractograms of the electrodes prepared with hydrothermal reduction with the three chemicals. The results shown correspond to the conditions in which the smallest crystallite sizes were obtained, i.e., $120^{\circ} \mathrm{C}$ for FA and ET and $160{ }^{\circ} \mathrm{C}$ for EG. The typical Pt diffraction peaks at $39.9^{\circ}, 46.2^{\circ}$, and $67.6^{\circ}$, corresponding to the $\mathrm{Pt}$ (111), Pt (200), and Pt (220) crystalline facets, respectively, can be visualized, confirming 
the formation of crystalline metallic Pt particles. The mean crystalline size, estimated from the Scherrer Equation (1), are represented in Figure 2 for the different reducing agents $/ \mathrm{Pt}$ molar ratios and temperatures. For the three reducing agents, the smallest crystallite size is always attained at the lowest temperatures. In the case of the reducing agent/Pt molar ratio, in the case of FA and EG, the smallest crystallite is obtained for the intermediate ratio of 200, whereas for ET, the optimum is obtained for 300 . As general fashions, lower temperatures and higher reducing agent proportions favor the formation of smaller $\mathrm{Pt}$ crystals. In the first case, higher temperatures promote the crystal growth due to the larger energy available for forming the more stable large Pt crystals [30]. In the case of the reducing agent loading, the tendencies are more complex. In general terms, a higher reducing agent loading reduces the crystallite size. In this condition, more nuclei can rapidly form and grow to a lower extent. Finally, larger crystallites are formed for EG compared to FA and ET. The necessary higher temperature for EG $\left(160-200{ }^{\circ} \mathrm{C}\right)$ compared to FA and ET $\left(120-160^{\circ} \mathrm{C}\right)$ can be a primary reason for this observation (see the Material and Methods section to understand the required higher temperatures for EG), as already observed within each reducing agent. In addition, we might speculate with the simpler and more rapid FA and ET oxidation onto the growing Pt particles compared to EG, leading, in this latter case, to the formation of lesser nuclei that can largely grow (see the later discussion on the different morphologies of the SEM images).

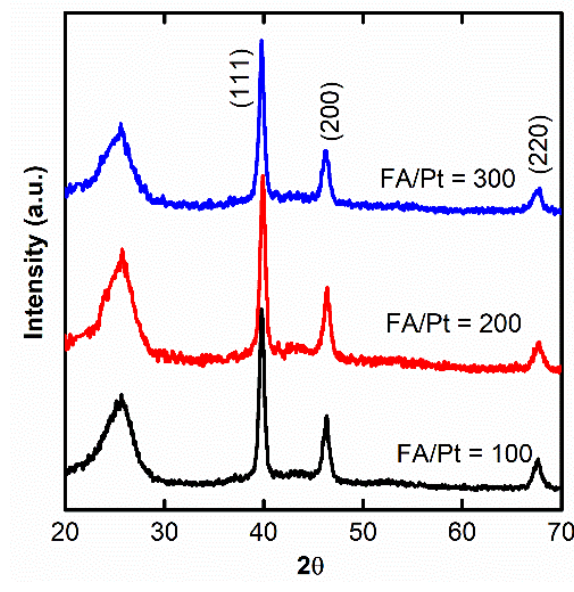

(a)

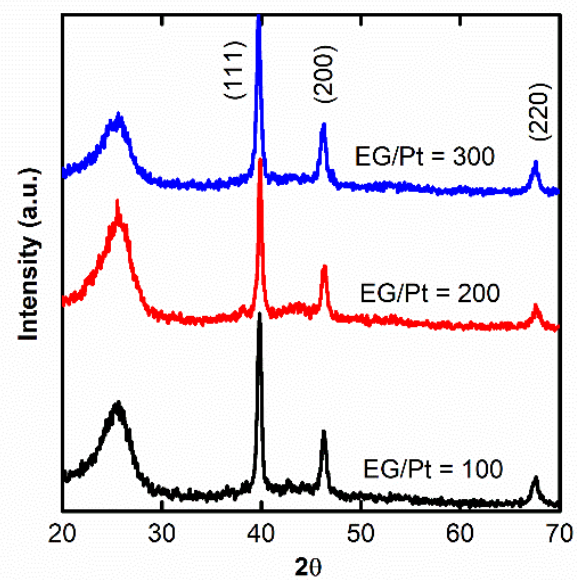

(b)

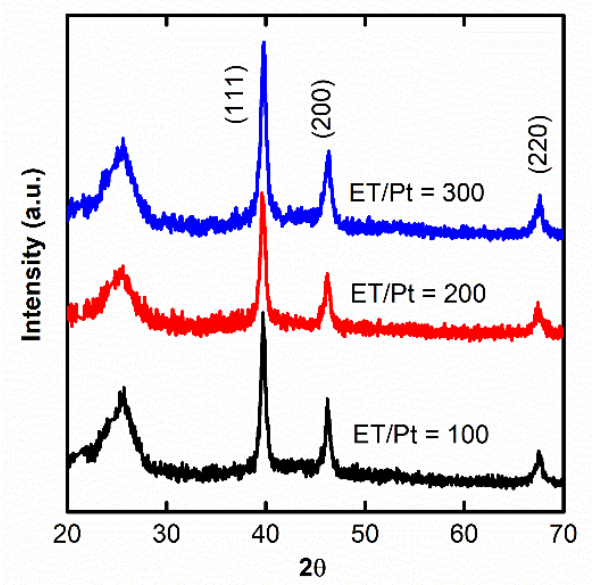

(c)

Figure 1. XRD patterns of the different electrocatalysts: (a) reduction with FA at $120^{\circ} \mathrm{C}$; (b) reduction with EG at $160{ }^{\circ} \mathrm{C}$; (c) reduction with ET at $120^{\circ} \mathrm{C}$. 


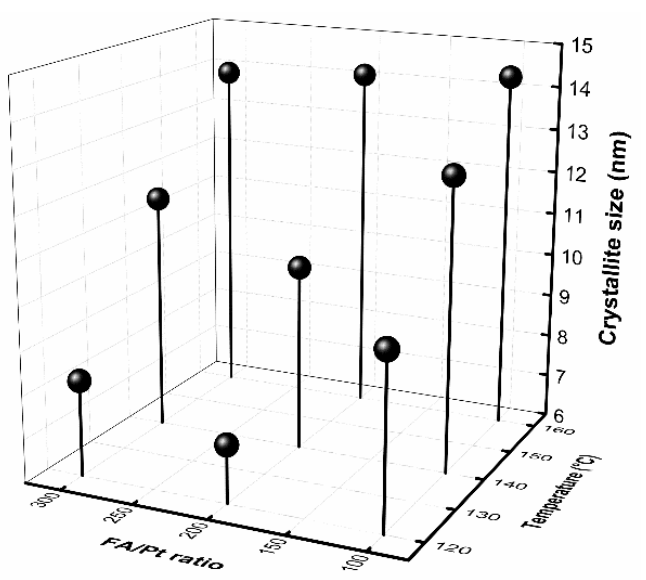

(a)

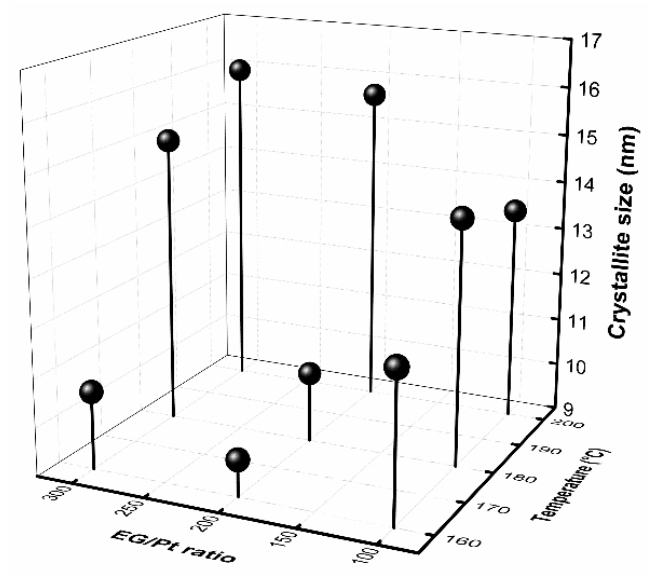

(b)

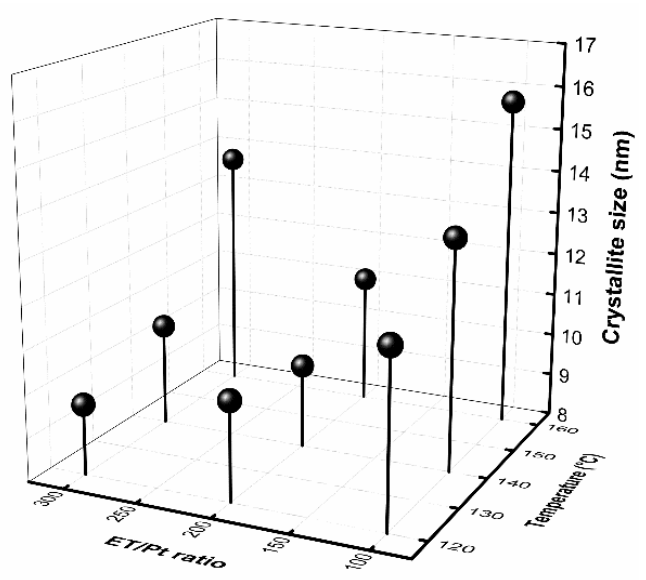

(c)

Figure 2. Average crystallite size of the Pt@DL electrodes prepared with different reducing agents under different concentrations and temperatures during the hydrothermal treatment: (a) FA; (b) EG; (c) EG.

Figure 3 shows the SEM images of the materials with the smallest crystallite sizes. As can be observed, the reduction of the Pt nanoparticles mainly occurs on the surface of the MPL. The Pt particles agglomerate in the form of micrometric dots irregularly distributed onto the surface. One possible reason for this lies in the "dry paint" state on which the reductive hydrothermal treatment is applied, favoring the phenomenon of agglomeration. Attending to the images, smaller-sized microparticles with a more 
homogeneous distribution are formed when FA is used as reducing agent, with a stalagmitelike structure. In the case of EG, a cauliflower structure can be clearly seen and, finally, for ET, the structure is polyp-like. It is important to note that even for the other conditions (reducing agent/Pt ratio and temperature), the observed morphologies are similar for the same reducing agent (see Supplementary Material, Figures S1-S6). Table 2 reports the corresponding average particle size from the SEM images, confirming the reduced average particle size and the larger homogeneity attained when FA is used as the reducing agent.

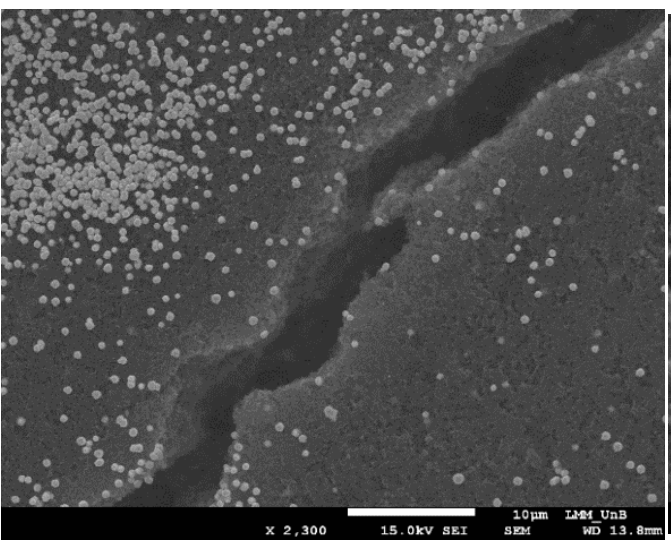

(a)

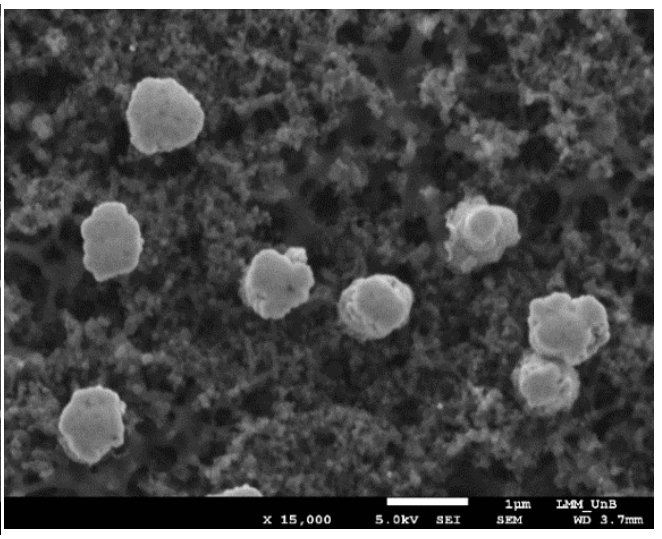

(b)

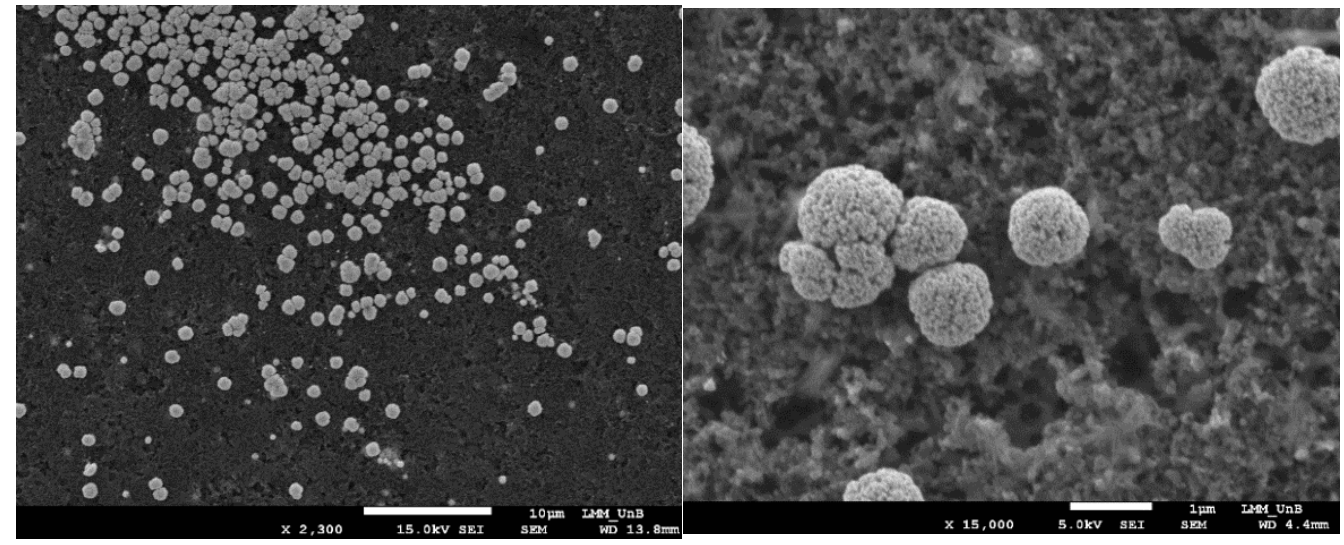

(c)

(d)

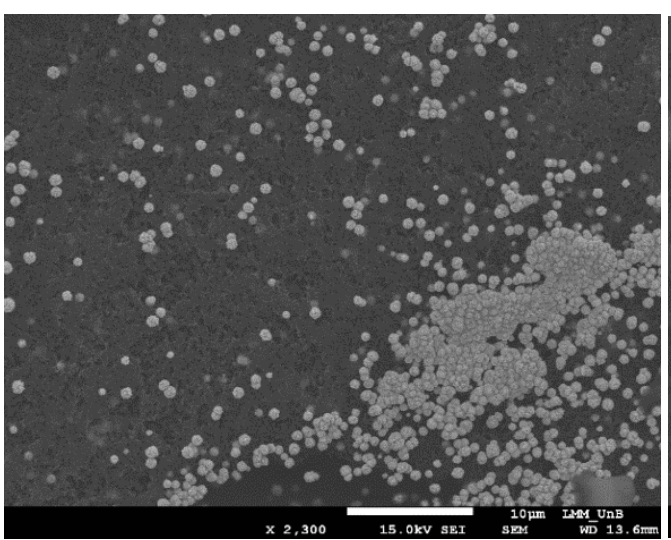

(e)

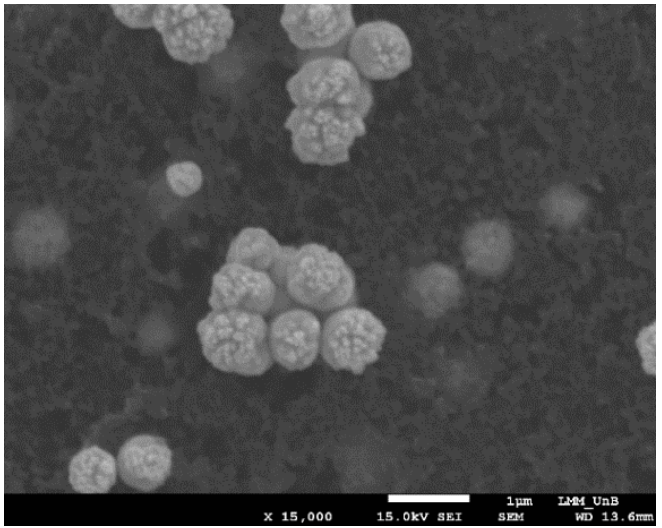

(f)

Figure 3. SEM images of the different Pt@DL catalysts hydrothermally reduced with (a,b) FA120200: (c,d) EG160200; (e,f) ET120300. 
Table 2. Average particle size for the Pt@GDL electrodes studied.

\begin{tabular}{cc}
\hline Electrode & Average Particle Size (nm) \\
\hline FA120200 & $669 \pm 191$ \\
EG160200 & $895 \pm 249$ \\
ET120300 & $761 \pm 385$ \\
\hline
\end{tabular}

Such different morphologies may be explained in terms of the oxidation mechanism followed by the different reducing compounds. In the case of EG, it is known that glycolic and oxalic acid are formed [31,32]. Both molecules may adsorb on the surface of the $\mathrm{Pt}$ particles and, in combination with the surfactant CTAB (synergistic effect), lead to the formation of the cauliflower structure. In the case of ethanol and formic acid, their oxidation leads to the formation of acetaldehyde [33-35] and $\mathrm{CO}_{2}$ [16]. Acetaldehyde is a very volatile molecule that might not adsorb so intensely onto the growing $\mathrm{Pt}$ surface, leading to an "intermediate" polyp-like structure. $\mathrm{CO}_{2}$ is expected to be readily released from the Pt surface, leading to an apparent dense structure. As a common feature, the three types of materials present a bottom-up structure of the Pt particles, which can be explained by the ascending vapor flux within the reactor. SEM micrographies corresponding to other reducing conditions are displayed in the Supplementary Material. Regarding the EDS results, no bromide was detected, which is indicative of the successful removal of CTAB.

\subsection{Single-Cell Results}

The prepared electrodes were tested for formic acid and ethanol electro-oxidation in a high-temperature PBI-based MEA single cell. Figure 4 displays the corresponding polarization and power curves for the FA120200 MEA (smallest crystal size) operating with formic acid (Figure 4a) and ethanol (Figure $4 b$ ).

As can be observed, the prepared electrodes are active for high-temperature PBIbased DFAFC and DEFC. An enhancement in the performance is observed the higher the temperature due to the faster FA and ET electro-oxidation and $\mathrm{O}_{2}$ electro-reduction, as well as the increase in the membrane conductivity and in the tolerance of the cathode for the fuel crossover [12-14]. In the case of FA, the maximum power outputs are 0.0103, 0.0168, and $0.025 \mathrm{~W} \mathrm{~cm}^{-2}$ at 150,175 , and $200{ }^{\circ} \mathrm{C}$, respectively, whereas for ET, the corresponding maximum power outputs are $0.0032,0.0052$, and $0.0070 \mathrm{~W} \mathrm{~cm}^{-2}$ at 150,175 , and $200{ }^{\circ} \mathrm{C}$, respectively. The more complex ET electro-oxidation through the formation of strongly adsorbed species such as $\mathrm{CH}_{3} \mathrm{CO}_{a d s}, \mathrm{CH}_{\mathrm{x} \text {,ads }}$, and $\mathrm{CO}_{\text {ads }}$ explains the lower performance compared to $\mathrm{FA}\left(\mathrm{CO}_{\mathrm{ads}}\right)$. In both sets of experiments, some fluctuations are observed. These are due to the irregularity in the vaporized flow of fuel associated to the pulsing flow of the peristaltic pump. Improvements in the vaporizer are being executed in order to minimize this phenomenon for future studies. It is interesting to remark that this study, to our best knowledge, presents the first results for a high-temperature PBI-based DFAFC. The polarization and power DFAFC and DEFC curves confirm the suitability of the prepared electrodes for their application in, in this case, high-temperature PBI-based PEMFC. 


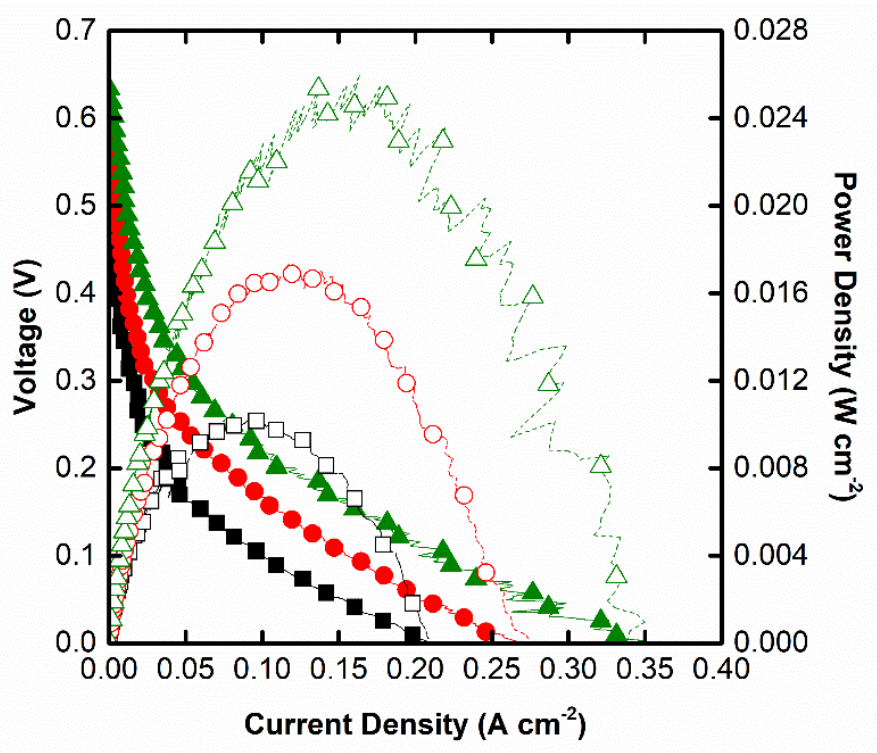

(a)

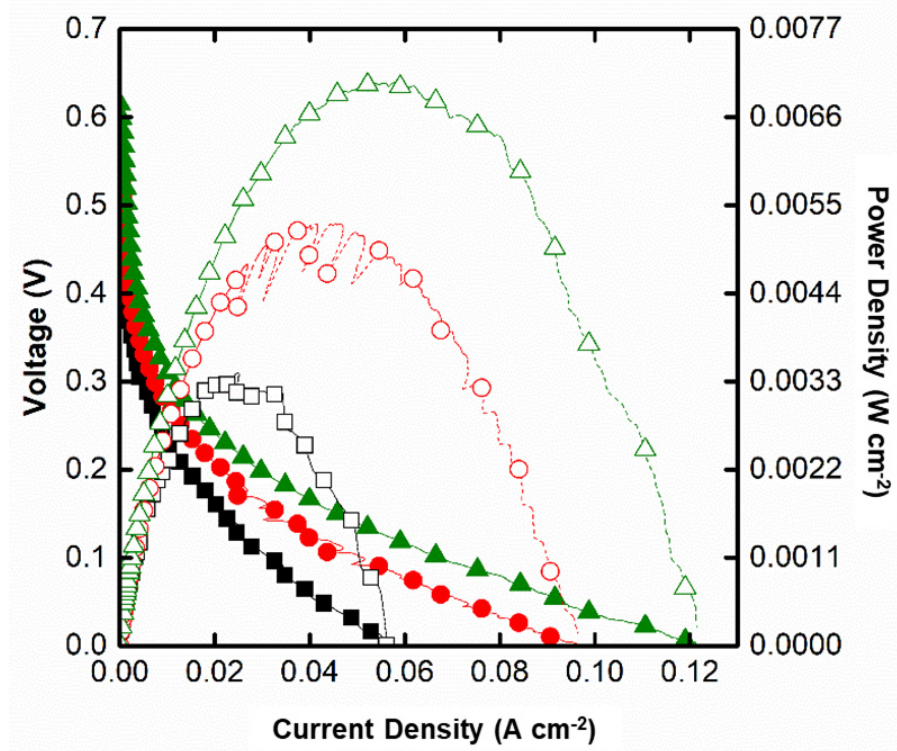

(b)

Figure 4. Polarization curves for: (a) PBI-based DFAFC; and (b) PBI-based DEFC for different temperatures $\left(\square: 150^{\circ} \mathrm{C}, \bullet \bigcirc: 175^{\circ} \mathrm{C}, \triangle \triangle: 200^{\circ} \mathrm{C}\right.$; solid symbols: cell voltage, hollow symbols: cell power output; anode and cathode prepared by the hydrothermal reduction).

Figure 5 shows the maximum power densities for three reducing agents used. As can be observed, the performance of the Pt@GDL electrodes prepared by hydrothermal reduction in FA is superior to the other reducing agents regardless of the temperature and fuel used (DFAFC or DEFC) as a result of the apparent effect attributed to the smaller particle sizes. In addition, the lowest performance of the EG-prepared Pt@GDL may be attributed to the presence of glycolic and oxalic acid adsorbed onto the Pt surface as a result of the EG oxidation during the Pt particles' growth. Nevertheless, we believe that these results could be notably enhanced after an intense optimization work in order to overcome two observed limitations: (a) some percolation of the platinum solution initially used to prepare the electrode; and (b) certain agglomeration of the formed Pt particles. We are also working on the preparation of supported Pt nanoparticles in the expectation of diminishing the observed shortcomings to further promote the electrochemical performances, although 
these first results have been considered stimulating for this initial stage. In addition, we believe that this strategy for preparing fuel cell electrodes could be also extrapolated to the traditional low-temperature PEMFC. As references, Linares et al. $[13,14]$ tested traditionally carbon supported $\mathrm{Pt} / \mathrm{C}$ as anodic material for PA-doped PBI-based DEFC with a maximum power density of $0.015 \mathrm{~W} \mathrm{~cm}^{-2}$ at $150{ }^{\circ} \mathrm{C}$ and $0.03 \mathrm{~W} \mathrm{~cm}^{-2}$ at $200{ }^{\circ} \mathrm{C}$. Our results are still inferior to those presented in [36]. However, there is room for further improvement in order to increase the cell performance.

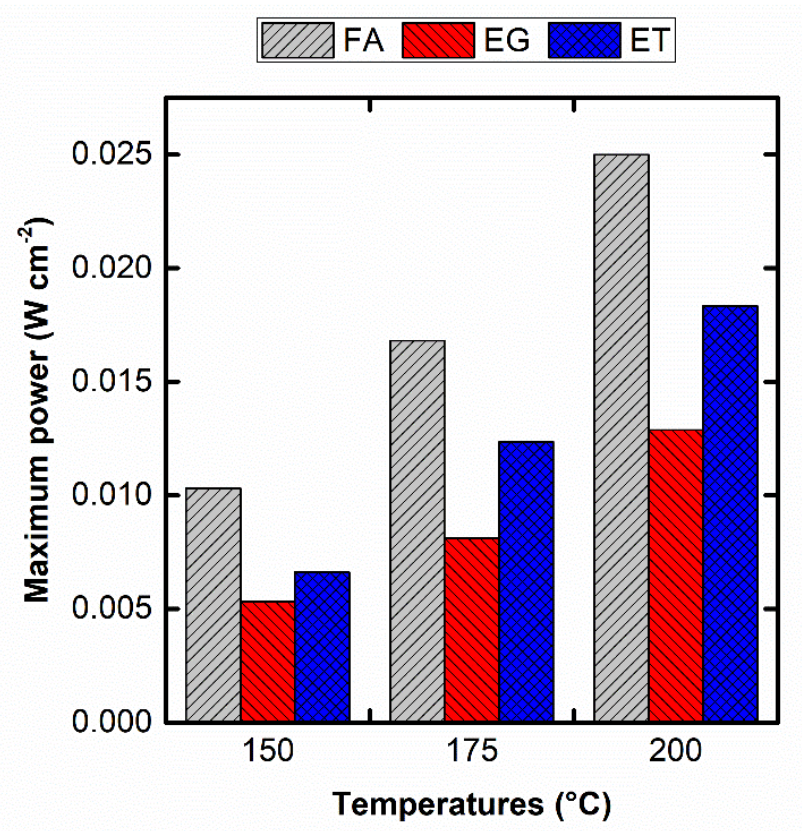

(a)

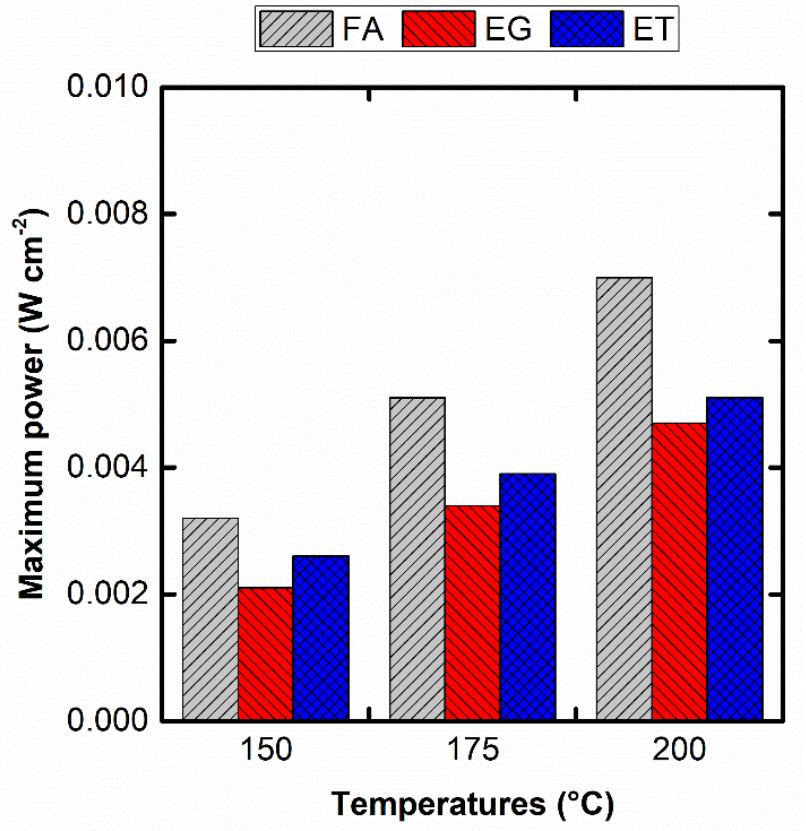

(b)

Figure 5. Maximum power densities at the different temperatures for the three used reducing agents, FA120200, EG160200, and ET120300 for: (a) DFAFC and (b) DEFC.

\section{Materials and Methods}

In a first stage, the precursor solution was prepared by mixing in an ultrasonic bath $0.4 \mathrm{~mL}$ of ethanol (Dinâmica, São Paulo, SP, Brazil), $0.5 \mathrm{~mL}$ of a $0.02 \mathrm{~mol} \mathrm{~L}^{-1}$ hexchloro- 
platinic acid (Sigma-Aldrich, Burlington, MA, USA) solution, and $9 \mathrm{mg}$ of cetyltrimethylammonium bromide (CTAB) for $5 \mathrm{~min}$. Such volumes came from preliminary studies carried out on the commercial GDL ELAT-1400W (De Nora North America, USA, formed by carbon cloth and a teflonized MPL), in which the solution was spread onto the front side containing the wet-proofed MPL. Ethanol was found to be the best solvent to prepare, disperse, and more homogeneously deposit the impregnation solution. Water, acetone, and hexane did not render uniform distributions due to a high interfacial tension or full permeation of the solution through the GDL. Higher ethanol volumes resulted in the permeation of the precursor solution to the backside, which would result in a reduction of the Pt utilization by poor contact between the CL and the polymeric electrolyte. Lower ethanol volumes did not allow a uniform distribution of the solution. In a similar manner, $\mathrm{CTAB}$ is necessary for the adequate dispersion of the precursor solution to reduce the interfacial tension. The amount of platinum salt corresponded to an expected Pt loading of $0.5 \mathrm{mg} \mathrm{cm}^{-2}$ in $4 \mathrm{~cm}^{2}$ prepared electrodes. Next, the impregnated GDL is dried on a hot plate at a temperature of $80^{\circ} \mathrm{C}$ for $30 \mathrm{~min}$.

Next, the "impregnated" GDL was placed on top of a fixed bed formed by a glass sphere within a $20 \mathrm{~mL}$ Teflon-lined stainless-steel autoclave. Ethanol, formic acid, and ethylene glycol were added to $1 \mathrm{~mL}$ of water to provide autogenous pressurization under hydrothermal conditions. The amounts of the reducing agents were adjusted to render molar ratios of 100, 200, and 300 with respect to the Pt atomic loading. The autoclave was heated to 120,140 , and $160^{\circ} \mathrm{C}$ for the more volatile FA and ET, whereas higher temperatures, 160,180 , and $200{ }^{\circ} \mathrm{C}$ were required for EG. The reduction time was fixed at $24 \mathrm{~h}$. The obtained Pt@GDL were thoroughly washed with ultrapure water any nonreduced Pt salt and $\mathrm{CTAB}$, dried in an oven at $50{ }^{\circ} \mathrm{C}$, and stored for future uses. It is important to note that lower reducing temperatures did not allow the complete reduction of the salt precursor to $\mathrm{Pt}^{0}$, as observed by the rapid appearance of yellow color in the washing waters and shift to pink after adding a drop of a KI solution [36].

To confirm the Pt loading, a TA was proposed by calcinating the GDL in air at $800{ }^{\circ} \mathrm{C}$ in an oven for $3 \mathrm{~h}$. For this, a blank was carried out with the GDL to estimate the ash content. Next, the same procedure was applied to the prepared Pt@GDL materials. The remaining ashes were weighed to quantify the Pt loading. XRD data were obtained with a Bruker powder diffractometer (model D8 Focus) with the radiation from a copper tube $\left(\lambda_{\mathrm{K} \alpha}=1.5406 \AA\right)$, operating at $40 \mathrm{kV}$ and $30 \mathrm{~mA}$, and scanning rate of $2^{\circ} \mathrm{min}^{-1}$ (20 from 20 to $90^{\circ}$, step $\left.0.02^{\circ}\right)$. Pt@GDL $\left(2.0 \times 2.0 \mathrm{~cm}^{2}\right)$ was fixed on the top of the sample holder. The mean size of Pt particles was calculated from Scherrer Equation (1) applied on a diffraction peak corresponding to the $2 \theta$ angle position of the $\mathrm{Pt}(220)$ facet. The parameter $\beta_{2 \theta}$ is the peak width at the half-height. The micrographies and the EDS spectra were obtained by a JEOL JSM 7001F Scanning Electron Microscope.

$$
\mathrm{d}=\frac{0.9 \lambda}{\beta_{2 \theta} \cos \theta}
$$

Before the preparation of the MEA, the electrodes were impregnated with $30 \mathrm{mg} \mathrm{cm}^{-2}$ of $10 \mathrm{wt} \% \mathrm{H}_{3} \mathrm{PO}_{4}$ solution and left to dry for $12 \mathrm{~h}$. Then, the electrodes were sandwiched between a PA-PBI $\left(3 \times 3 \mathrm{~cm}^{2}\right)$ and hot-pressed at $150{ }^{\circ} \mathrm{C}$ for $3 \mathrm{~min}$ applying a pneumatic pressure of 2 ton.

MEA electrochemical activity for DFAFC and DEFC were carried out in a system whose scheme is displayed in Figure 6. A peristaltic pump was used for regulating the fuel flowrate (fixed at $0.5 \mathrm{~mL} \mathrm{~min}^{-1}$ for both ethanol and formic acid) and a vaporizer quartz tube connected to the anode entrance. Pure oxygen flow was regulated at $30 \mathrm{STP} \mathrm{mL} \mathrm{min}{ }^{-1}$ for the cathode. Solutions with a formic acid/water volume ratio of 8:1 and ethanol/water ratio of 1:2 were fed to the cell. The electrochemical performance was assessed with the aid of a potentiostat/galvanostat PGSTAT 302N in the Linear Sweep Voltammetry mode at a scan rate of $0.5 \mathrm{mV} \mathrm{s}^{-1}$. 


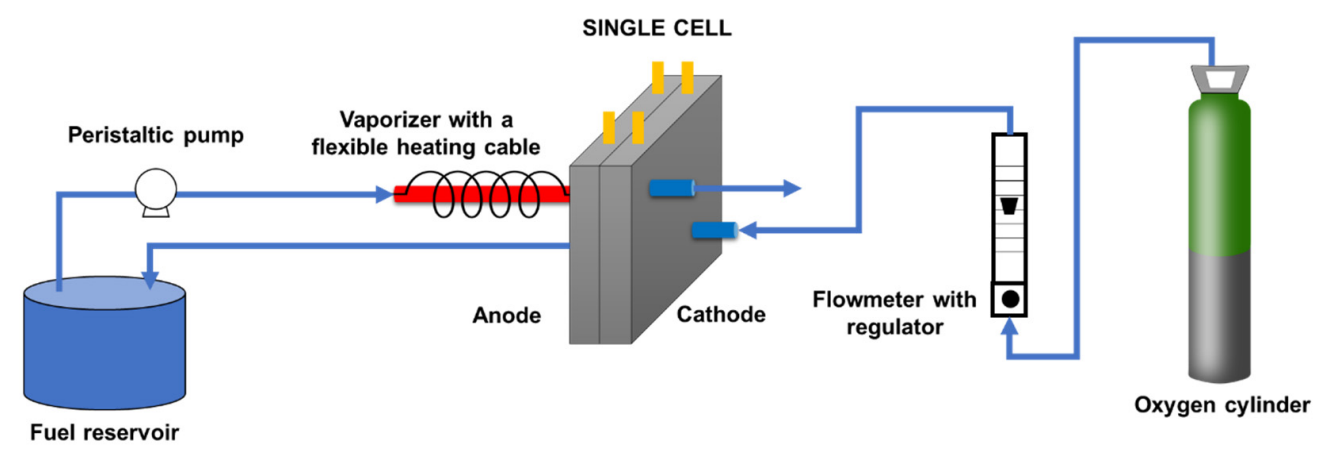

Figure 6. Scheme of the experimental setup for the single-cell studies of the prepared MEA.

\section{Conclusions}

This paper has demonstrated that it is possible to directly prepare a catalytic layer by deposition of the Pt salt precursor onto the diffusion layer by a hydrothermal reduction with three different reducing agents, formic acid, ethylene glycol, and ethanol. All of them are able to reduce the Pt precursor to metallic Pt, leading to different crystallite sizes depending on the molar ratio $\mathrm{Pt} /$ reducing agent and the temperature (smallest particles obtained for FA at $120^{\circ} \mathrm{C}$ and an intermediate Pt/FA molar ratio of 200). More interestingly, the electrodes prepared have demonstrated to be active for high-temperature PBI-based DEFC and DFAFC. Thus, the presented method, although it still demands of improvement, may be an alternative for an easier and rapid preparation of the CL.

Supplementary Materials: The following are available online at https: / www.mdpi.com/article/ 10.3390/catal11101246/s1, Figure S1: SEM image of the FA160300; Figure S2: SEM image of the FA160300; Figure S3: SEM image of the EG200300; Figure S4: SEM image of the EG200200; Figure S5: SEM image of the ET160100; Figure S6. SEM image of the ET160300.

Author Contributions: Conceptualization, R.C., J.J.L. and G.A.V.M.; Methodology, M.C.H.C., R.C., J.J.L. and G.A.V.M.; Formal analysis, M.C.H.C., S.C.L.D., J.A.D., R.C., J.J.L. and G.A.V.M.; Investigation, B.S.d.C., R.d.S.C. and S.d.A.D.; Resources, S.C.L.D., J.A.D., R.C., J.J.L. and G.A.V.M.; Data curation, M.C.H.C., S.C.L.D., J.A.D., R.C., J.J.L. and G.A.V.M.; Writing-original draft preparation, M.C.H.C., S.C.L.D., J.A.D., R.C., J.J.L. and G.A.V.M.; Writing-review and editing, M.C.H.C., S.C.L.D., J.A.D., R.C., J.J.L. and G.A.V.M.; Supervision, M.C.H.C., R.C., J.J.L. and G.A.V.M.; Project administration, G.A.V.M.; Funding acquisition, S.C.L.D., J.A.D., R.C., J.J.L. and G.A.V.M. All authors have read and agreed to the published version of the manuscript.

Funding: We acknowledge CNPq (grants $n^{\circ} 307845 / 2019-2$ and 307091/2018-0) and CAPES (grant $n^{\circ}$ 001), and in particular, R.d.S.C., B.S.d.C., and S.d.A.D. thank CNPq for the scholarship awarded to them.

Data Availability Statement: The data presented in this study are available on request from the corresponding author. The data are not publicly available due to privacy restrictions.

Acknowledgments: We would like to deeply thank Ingrid Gracielle Martins da Silva, Matheus Ramos Guimarães Medeiros and Sôniar Nair Báo for the support in the execution of the SEM and EDX measurements in the Laboratório de Microscopia e Microanálise (LMM), Institute of Biology, University of Brasilia.

Conflicts of Interest: The authors declare no conflict of interest.

\section{References}

1. Bigerna, S.; Bollino, C.A.; Polinori, P. Convergence in Renewable Energy Sources Diffusion Worldwide. J. Environ. Manag. 2021, 292, 112784. [CrossRef]

2. Edeh, I. Bioethanol Production: An Overview. In Bioethanol [Working Title]; IntechOpen: London, UK, 2020.

3. Chen, X.; Liu, Y.; Wu, J. Sustainable Production of Formic Acid from Biomass and Carbon Dioxide. Mol. Catal. 2020, $483,110716$. [CrossRef]

4. Fuel Ethanol Production in Major Countries 2020. Available online: https://www.statista.com/statistics/281606/ethanolproduction-in-selected-countries/ (accessed on 11 August 2021). 
5. Friedl, J.; Stimming, U. Model Catalyst Studies on Hydrogen and Ethanol Oxidation for Fuel Cells. Electrochim. Acta 2013, 101, 41-58. [CrossRef]

6. Müller, K.; Brooks, K.; Autrey, T. Hydrogen Storage in Formic Acid: A Comparison of Process Options. Energy Fuels 2017, 31, 12603-12611. [CrossRef]

7. Singh, A.K.; Singh, S.; Kumar, A. Hydrogen Energy Future with Formic Acid: A Renewable Chemical Hydrogen Storage System. Catal. Sci. Technol. 2015, 6, 12-40. [CrossRef]

8. Kawanami, H.; Himeda, Y.; Laurenczy, G. Formic Acid as a Hydrogen Carrier for Fuel Cells Toward a Sustainable Energy System. In Advances in Inorganic Chemistry; van Eldik, R., Hubbard, C.D., Eds.; Inorganic Reaction Mechanisms; Academic Press: Cambridge, MA, USA, 2017; Volume 70, pp. 395-427.

9. Barbir, F. Fuel Cell Applications. In PEM Fuel Cells, 2nd ed.; Barbir, F., Ed.; Academic Press: Boston, MA, USA, 2013 ; pp. 373-434. ISBN 978-0-12-387710-9.

10. Shaari, N.; Kamarudin, S.K.; Bahru, R.; Osman, S.H.; Md Ishak, N.A.I. Progress and Challenges: Review for Direct Liquid Fuel Cell. Int. J. Energy Res. 2021, 45, 6644-6688. [CrossRef]

11. Yaqoob, L.; Noor, T.; Iqbal, N. A Comprehensive and Critical Review of the Recent Progress in Electrocatalysts for the Ethanol Oxidation Reaction. RSC Adv. 2021, 11, 16768-16804. [CrossRef]

12. Lobato, J.; Cañizares, P.; Rodrigo, M.A.; Linares, J.J. Testing a Vapour-Fed PBI-Based Direct Ethanol Fuel Cell. Fuel Cells 2009, 9 , 597-604. [CrossRef]

13. Linares, J.J.; Rocha, T.A.; Zignani, S.; Paganin, V.A.; Gonzalez, E.R. Different Anode Catalyst for High Temperature Polybenzimidazole-Based Direct Ethanol Fuel Cells. Int. J. Hydrogen Energy 2013, 38, 620-630. [CrossRef]

14. Linares, J.J.; Zignani, S.C.; Rocha, T.A.; Gonzalez, E.R. Ethanol Oxidation on a High Temperature PBI-Based DEFC Using Pt/C, $\mathrm{PtRu} / \mathrm{C}$ and Pt3Sn/C as Catalysts. J. Appl. Electrochem. 2013, 43, 147-158. [CrossRef]

15. Lobato, J.; Cañizares, P.; Rodrigo, M.A.; Linares, J.J. Study of Different Bimetallic Anodic Catalysts Supported on Carbon for a High Temperature Polybenzimidazole-Based Direct Ethanol Fuel Cell. Appl. Catal. B Environ. 2009, 91, 269-274. [CrossRef]

16. Weber, M. Formic Acid Oxidation in a Polymer Electrolyte Fuel Cell. J. Electrochem. Soc. 1996, 143, L158-L160. [CrossRef]

17. Rath, R.; Kumar, P.; Unnikrishnan, L.; Mohanty, S.; Nayak, S.K. Current Scenario of Poly (2,5-Benzimidazole) (ABPBI) as Prospective PEM for Application in HT-PEMFC. Polym. Rev. 2020, 60, 267-317. [CrossRef]

18. Escorihuela, J.; Olvera-Mancilla, J.; Alexandrova, L.; del Castillo, L.F.; Compañ, V. Recent Progress in the Development of Composite Membranes Based on Polybenzimidazole for High Temperature Proton Exchange Membrane (PEM) Fuel Cell Applications. Polymers 2020, 12, 1861. [CrossRef]

19. Aili, D.; Henkensmeier, D.; Martin, S.; Singh, B.; Hu, Y.; Jensen, J.O.; Cleemann, L.N.; Li, Q. Polybenzimidazole-Based HighTemperature Polymer Electrolyte Membrane Fuel Cells: New Insights and Recent Progress. Electrochem. Energy Rev. 2020, 3 , 793-845. [CrossRef]

20. Zhou, Z.; Zholobko, O.; Wu, X.-F.; Aulich, T.; Thakare, J.; Hurley, J. Polybenzimidazole-Based Polymer Electrolyte Membranes for High-Temperature Fuel Cells: Current Status and Prospects. Energies 2021, 14, 135. [CrossRef]

21. Fouzaï, I.; Gentil, S.; Bassetto, V.C.; Silva, W.O.; Maher, R.; Girault, H.H. Catalytic Layer-Membrane Electrode Assembly Methods for Optimum Triple Phase Boundaries and Fuel Cell Performances. J. Mater. Chem. A 2021, 9, 11096-11123. [CrossRef]

22. Schröder, J.; Mints, V.A.; Bornet, A.; Berner, E.; Fathi Tovini, M.; Quinson, J.; Wiberg, G.K.H.; Bizzotto, F.; El-Sayed, H.A.; Arenz, M. The Gas Diffusion Electrode Setup as Straightforward Testing Device for Proton Exchange Membrane Water Electrolyzer Catalysts. JACS Au 2021, 1, 247-251. [CrossRef] [PubMed]

23. Salomé, S.; Rego, R.; Oliveira, M.C. Development of Silver-Gas Diffusion Electrodes for the Oxygen Reduction Reaction by Electrodeposition. Mater. Chem. Phys. 2013, 143, 109-115. [CrossRef]

24. Pacquets, L.; Irtem, E.; Neukermans, S.; Daems, N.; Bals, S.; Breugelmans, T. Size-Controlled Electrodeposition of Cu Nanoparticles on Gas Diffusion Electrodes in Methanesulfonic Acid Solution. J. Appl. Electrochem. 2021, 51, 317-330. [CrossRef]

25. Nguyen, T.N.; Dinh, C.-T. Gas Diffusion Electrode Design for Electrochemical Carbon Dioxide Reduction. Chem. Soc. Rev. 2020, 49, 7488-7504. [CrossRef]

26. Kim, Y.; Karuppannan, M.; Sung, Y.-E.; Lim, T.; Kwon, O.J. Direct Formation of Pt Catalyst on Gas Diffusion Layer Using Sonochemical Deposition Method for the Application in Polymer Electrolyte Membrane Fuel Cell. Int. J. Hydrogen Energy 2018, 43, 10431-10439. [CrossRef]

27. Nores-Pondal, F.J.; Vilella, I.M.J.; Troiani, H.; Granada, M.; de Miguel, S.R.; Scelza, O.A.; Corti, H.R. Catalytic Activity vs. Size Correlation in Platinum Catalysts of PEM Fuel Cells Prepared on Carbon Black by Different Methods. Int. J. Hydrogen Energy 2009, 34, 8193-8203. [CrossRef]

28. Gago, A.S.; Habrioux, A.; Alonso-Vante, N. Tailoring Nanostructured Catalysts for Electrochemical Energy Conversion Systems. Nanotechnol. Rev. 2012, 1, 427-453. [CrossRef]

29. Almeida, T.S.; Palma, L.M.; Leonello, P.H.; Morais, C.; Kokoh, K.B.; Andrade, A.R.D. An Optimization Study of PtSn/C Catalysts Applied to Direct Ethanol Fuel Cell: Effect of the Preparation Method on the Electrocatalytic Activity of the Catalysts. J. Power Sources 2012, 215, 53-62. [CrossRef]

30. Hornyak, G.L.; Tibbals, H.F.; Dutta, J.; Moore, J.J. Chemical Nanoengineering. In Introduction to Nanoscience and Nanotechnology; CRC Press: Boca Raton, FL, USA, 2008; ISBN 978-0-429-14151-5. 
31. Sarma, L.S.; Chen, C.-H.; Kumar, S.M.S.; Wang, G.-R.; Yen, S.-C.; Liu, D.-G.; Sheu, H.-S.; Yu, K.-L.; Tang, M.-T.; Lee, J.-F.; et al. Formation of $\mathrm{Pt}-\mathrm{Ru}$ Nanoparticles in Ethylene Glycol Solution: An in Situ X-Ray Absorption Spectroscopy Study. Langmuir 2007, 23, 5802-5809. [CrossRef]

32. Bock, C.; Paquet, C.; Couillard, M.; Botton, G.A.; MacDougall, B.R. Size-Selected Synthesis of PtRu Nano-Catalysts: Reaction and Size Control Mechanism. J. Am. Chem. Soc. 2004, 126, 8028-8037. [CrossRef]

33. Deivaraj, T.C.; Lee, J.Y. Preparation of Carbon-Supported PtRu Nanoparticles for Direct Methanol Fuel Cell Applications-A Comparative Study. J. Power Sources 2005, 142, 43-49. [CrossRef]

34. Kashyout, A.B.; Youssef, B.A.B. Electrooxidation of Methanol on Carbon Supported Pt- Ru Nanocatalysts Prepared by Ethanol Reduction Method. Int. J. Electrochem. Sci. 2011, 6, 15.

35. Toshima, N.; Hirakawa, K. Polymer-Protected PtRu Bimetallic Cluster Catalysts for Visible-Light-Induced Hydrogen Generation from Water and Electron Transfer Dynamics. Appl. Surf. Sci. 1997, 121-122, 534-537. [CrossRef]

36. Balcerzak, M.; Pergół, K. Selective Determination of Platinum and Palladium in Iodide Media by Derivative Spectrophotometry. Chem. Anal. 2003, 48, 87-95. 